\title{
Konkyliens hemmelighet
}

Når man blar i gamle utgaver av Tidsskriftet, dukker det opp mange merkelige kasuistikker. Denne er hentet fra Tidsskriftet nr. 7/1934. Ifølge forfatteren utgjør beretninger om fremmedlegemer på ville veier en hel litteratur - men hans bidrag må vel være av de mer aparte. Hold deg for nesen og les (Tidsskr Nor Lægeforen 1934; 54: $344-6)$.

Fra Ullevål sykehus’ avd. III. Overlæge Hj. Schilling.

\section{Et eiendommelig fremmedlegeme i vagina.}

\author{
Av Paul Treider, Drammen.
}

Det finnes vel ikke den gjenstand av rimelig størrelse som man ikke kan finne igjen som fremmedlegeme i vagina. Kasuistiske meddelelser om sådanne utgjør en hel litteratur, og jeg skal hermed føie et lite bidrag til den. For bare å nevne nogen av de mange «bruksgjenstander» som efter lengere tid et blitt hentet ut: Et vannglass hadde ligget i 10 år, en vatt-tampon i 29 år, en snelle i 23 år, et pipehode i 10 år, og således kan man fortsette i det uendelige. Nesten alltid er disse gjenstander anvendt som masturbantia, en og annen gang har man holdepunkt for at eierinnen har forsøkt å holde et prolaps inne ved hjelp av slike «hjemmegjorte» pessar.

Ikke sjelden finner man fremmedlegemer hos barn, ofte flere år før pubertetsalderen, men da mindre ting som dog alltid gir anledning til stinkende utflod, - en sjelden tilstand i denne alder. Forøvrig er det ganske forbausende hvor lenge de kan ligge uten å lage større decubitus, men betendelse blir det naturligvis alltid. Som regel går det bra, meget sjelden ser man perforasjon til peritoneum, urinblære eller tykktarm.

Vår patient, 79 år gammel, var meget kjekk og åndsfrisk. Hun bodde $i$ et gamlehjem hvor hun efterhvert blev en plage for sine omgivelser - slik stank var der av henne. Til sist forlangte man, tross hennes iherdige protester, at hun skulde søke læge. Denne la henne inn i Ullevål sykehus, avd. III for stinkende utflod. Her var hun ikke særlig villig til å gi oplysninger; men vi fikk da ut av henne at hun siden 50-årsalderen hadde vært plaget av smerter i sakralregionen. I 10-15 år hadde hun hatt rikelig fluor som det nok hadde luktet av, de siste år også svie og kløe i vulva, og vannlatningen var hyppig og smertefull.

Ved undersøkelsen blev der ikke påvist noget særlig for man kom til eksplorasjonen. Like innenfor introitus vaginæ føltes en stor, stenhård tumor som nesten fylte hele bekkenkanalen. Ved forsøk på å bevege den angav hun smerte. Tumor buktet sig frem i rectum; men slimhinnen var fritt bevegelig over den.

Vi visste ikke riktig hvad dette skulde være. Vi tenkte naturligvis først på et forkalket myom og slett ikke på fremmedlegeme. Men før vi foretok nogen vaginal inspeksjon, sendte vi patienten til røntgenundersøkelse. Dagen efter var der til visitten lagt frem et høist eiendommelig røntgenogram. Det viste en massiv skygge av et stort legeme $\mathrm{i}$ det lille bekken som med en smal munnspalte og en lang tannrad gren mot oss. Likheten med et konkylie var slående.

Vi tok patienten inn på skiftestuen og fikk vår formodning bekreftet. Å fjerne fremmedlegemet var ikke nogen enkel sak. Men under de første forsøk gikk det heldigvis istykker. Bite for bite blev hentet ut. Inne i konkyliet var det sikkert et par hundre kubikkcentimeter

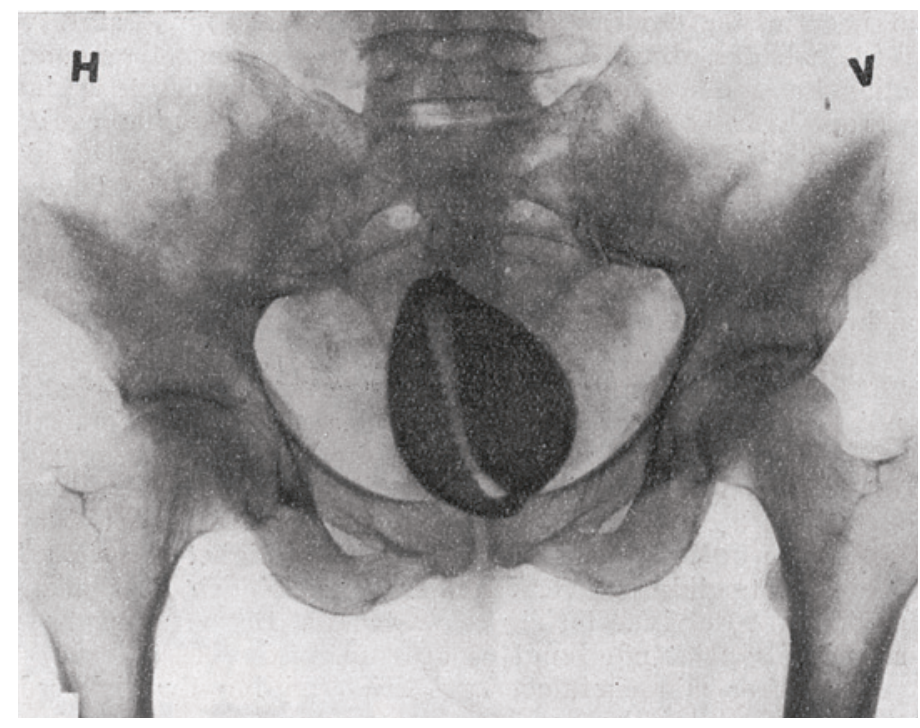

«gjørme», og adskillig av det samme stoff var retinert bak det. Lukten var mer enn avskyelig. Etter grundig skylling kunde man bare se en glatt, hyperemisk vaginalslimhinne hvor konkyliet hadde ligget. Portio hadde også et normalt utseende. Intet tegn til ulcerasjon noget sted. Det skal man nemlig være opmerksom på at der ikke så sjelden kommer kanserutvikling i decubitus-sår efter sådanne fremmedlegemer. $\mathrm{N} \mathrm{e} \mathrm{u} \mathrm{g} \mathrm{e} \mathrm{b} \mathrm{a} \mathrm{u} \mathrm{e} \mathrm{r} \mathrm{har} \mathrm{således} \mathrm{selv} \mathrm{beskrevet} 8$ tilfelle og samlet 6 fra litteraturen ; disse skulde alle være sikre kansere. Både den kliniske og histologiske diagnose er meget vanskelig å stille overfor reaktiv epitelhyperplasi som alltid kommer.

Patienten var synlig lettet, særlig efterat hun hadde fått grundig skylling et par dager. Vi gjorde nogen små, forsiktige forsøk på å få vite når og hvorledes konkyliet hadde forvillet sig dit inn ; men om den ting vilde hun ikke uttale sig; hun kunde da slett ikke høre eller forstå hvad vi sa. Vi hadde jo allikevel vår mistanke og lot henne beholde sin hemmelighet for sig selv.

Konkyliet gikk dessverre under uthentningen i så mange småstykker at det ikke lot sig rekonstruere. Det var meget tynt og skjørt, tilsynelatende langt på opløsningens vei.

Jeg takker min chef, overlæge Hj. Schilling for elskverdig tillatelse til å omtale kasus. 